\title{
PENGARUH PERCEIVED ORGANIZATIONAL SUPPORT, PROSEDURAL JUSTICE TERHADAP ORGANIZATIONAL CITIZENSHIP BEHAVIOR DENGAN KEPUASAN KERJA SEBAGAI VARIABEL MEDIASI PADA PERAWAT RSUD RASYDIN PADANG
}

\author{
Trio Candra Yoga ${ }^{1)}$, Yulihasri ${ }^{2)}$ \\ ${ }^{1)}$ Program Magister Manajemen, Fakultas Ekonomi, Universitas Andalas \\ Triocandrayoga389@gmail.com \\ ${ }^{2)}$ Program Magister Manajemen, Fakultas Ekonomi, Universitas Andalas \\ yulihasri@eb.unand.ac.id
}

\begin{abstract}
This study aims to examine and analyze the effect of perceived organizational support, procedural justice on organizational citizenship behavior mediated by job satisfaction in nurses at RSUD Rasydin Padang, West Sumatra. The population is all nurses at RSUD Rasydin Padang. The sampling method used was purposive sampling. The research data collection was carried out by distributing questionnaires to 137 respondents. Processing and data analysis was done using SmartPLS. The results showed that perceived organizational support, procedural justice and job satisfaction had a significant effect on organizational citizenship behavior, perceived organizational support, procedural justice had a significant effect on job satisfaction and satisfaction had a role as a partial mediation between perceived organizational support, procedural justice on organizational citizenship behavior.
\end{abstract}

Keywords: Perceived Organizational Support, Procedural Justice, Job Satisfaction, Organizational Citizenship Behavior

Abstrak : Penelitian ini bertujuan untuk menguji dan menganalisis pengaruh perceived organizational support, procedural justiceterhadap organizational citizenship behavior dimediasi oleh kepuasan kerja pada perawat RSUD Rasydin Padang, Sumatera Barat. Populasinya adalah seluruh perawat pada RSUD Rasydin Padang.Metode pengambilan sampel yang digunakan adalah purposive sampling.Pengumpulan data penelitian dilakukan dengan menyebarkan kuesioner kepada 137 responden.Pengolahan dan analisis data dilakukan dengan menggunakan SmartPLS. Hasil penelitian menunjukkan bahwa perceived organizational support, procedural justice dan kepuasan kerja berpengaruh signifikan terhadap organizational citizenship behavior, perceived organizational support, procedural justiceberpengaruh signifikan terhadap kepuasan kerjadankepuasan berperan sebagai mediasi parsial antara perceived organizational support, procedural justiceterhadap organizational citizenship behavior.

Kata kunci:Perceived Organizational Support, Procedural Justice, Kepuasan Kerja, Organizational Citizenship Behavior

\section{A. PENDAHULUAN}

Keberhasilan sebuah organisasi untuk bertahan hidup dalam jangka panjang disebabkan oleh kemampuan pegawai untuk mencapai kinerja terbaik.Didalam menjaga konsistensi pencapaian kinerja setiap perusahaan memiliki sejumlah tantangan yang harus dihadapi yang berhubungan dengan kompetensi diri yang dimiliki masing-masing pegawai.Mengingat banyak pegawai yang kewalahan ketika harus menghadapi bidang pekerjaan yang tidak sesuai dengan pengalaman dan kompetensi diri yang mereka miliki. Pada umumnya pegawai akan menghindari pekerjaan yang tidak sesuai dengan kompetensi diri mereka, atau tetap melaksanakannya akan tetapi pencapaian hasil yang diperoleh tidak optimal bagi organisasi.Keberhasilan sebuah organisasi untuk bertahan hidup dalam jangka panjang disebabkan oleh kemampuan pegawai untuk mencapai kinerja terbaik. 
Didalam menjaga konsistensi pencapaian kinerja setiap perusahaan memiliki sejumlah tantangan yang harus dihadapi yang berhubungan dengan kompetensi diri yang dimiliki masingmasing pegawai.Mengingat banyak pegawai yang kewalahan ketika harus menghadapi bidang pekerjaan yang tidak sesuai dengan pengalaman dan kompetensi diri yang mereka miliki. Pada umumnya pegawai akan menghindari pekerjaan yang tidak sesuai dengan kompetensi diri mereka, atau tetap melaksanakannya akan tetapi pencapaian hasil yang diperoleh tidak optimal bagi organisasi. Berdasarkan data yang diperoleh pada bagian personalia RSUD Rasyidin Padang terlihat prilaku kerja pegawai seperti terlihat pada Tabel 1 dibawah ini:

Tabel 1.Data Absensi Perawat RSUD RASYDIN Padang2019-2020

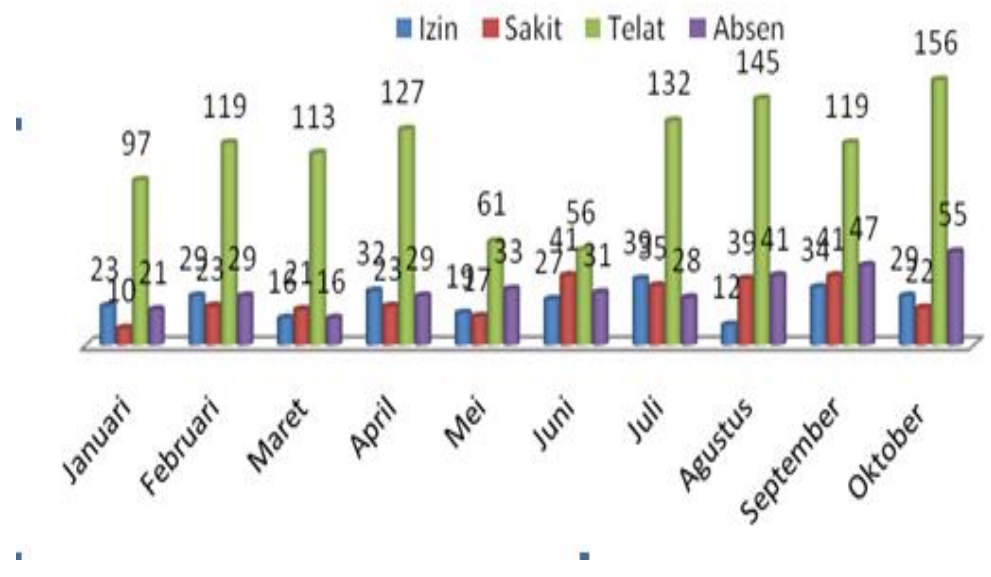

Pada Tabel 1.1 terlihat bahwa tingkat keterlambatan pegawai dari bulan kebulan mengalami peningkatan di RSUD Rasyidin Padang, hal ini menunjukan masih rendahnya prilaku perawat untuk memenuhi syarat minimum kehadiran dan kepatuhan terhadap aturan yang telah diterapkan, keadaan ini menunjukan masih rendahnya perilaku yang melampaui apa yang diperlukan oleh organisasi, seperti ketepatan waktu dan kepatuhan terhadap aturan dan peraturan organisasi, hal tersebut menggambarkan masih rendahnya perilaku organizational citizenship behavior pada Perawat RSUD Rasyidin Padang. Pada saat saya melakukan wawancara pada salah satu perawat yang ada di RSUD Rasydin Padang tentang pelaksanaan kegiatan sosial yang di lakukan oleh pihak Rumah Sakit di sekitar lingkungan Rumah Sakit tersebut, dia menjelaskan bahwa tida seluruhnya perawat yang ikut dalam pelaksanaan kegiatan sosial tersebut. Hal tersebut menunjukan atau mengindikasikan bahwa masih rendahnya perilaki organizational chitizenship behavior di RSUD Rasydin Padang Tersebut.Buruknya mutu pelayanan RSUD Rasyidin Padang salah satunya disebabkan oleh rendahnya perilaku organizational citizenship behavior didalam organisasi.

\section{Organizational Citizenship Behavior}

Organizational citizenship behaviour sangat penting artinya untuk menunjang keefektifan fungsi-fungsi organisasi, terutama dalam jangka panjang.Menurut (Gibson, 2009) menyatakan bahwa organizational citizenship behaviour mempengaruhi keefektifan organisasi karena beberapa alasan.Pertama, organizational citizenship bahavior dapat membantu meningkatkan produktivitas rekan kerja.Kedua, organizational citizenship behaviour dapat membantu meningkatkan produktivitas manajerial.Ketiga, organizational citizenship behaviour dapat membantu mengefisienkan penggunaan sumber daya organisasional untuk tujuan-tujuan produktif.

Keempat, organizational citizenship bahavior dapat menurunkan tingkat kebutuhan akan penyediaan sumber daya organisasi secara umum untuk tujuan-tujuan pemeliharaan karyawan. Kelima, organizational citizenship behaviour dapat dijadikan sebagai dasar yang efektif untuk aktivitas-aktivitas koordinasi antara anggota-anggota tim dan antara kelompok- 
kelompok kerja. Keenam, organizational citizenship behaviour dapat meningkatkan kemampuan organisasi untuk mendapatkan dan mempertahankan sumber daya manusia yang handal dengan memberikan kesan bahwa organisasi merupakan tempat bekerja yang lebih menarik.Ketujuh, organizational citizenship behaviour dapat meningkatkan stabilitas kinerja organisasi.Dan terakhir, organizational citizenship behaviour dapat meningkatkan kemampuan organisasi untuk beradaptasi terhadap perubahan-perubahan lingkungannya. Organ mendefinisikan organizational citizenship behaviour sebagai perilaku individual yang bersifat bebas (discretionary), yang tidak secara langsung dan eksplisit mendapat penghargaan dari sistem imbalan formal, dan yang secara keseluruhan mendorong keefektifan fungsi-fungsi organisasi.

Bersifat bebas dan sukarela, karena perilaku tersebut tidak diharuskan oleh persyaratan peran atau deskripsi jabatan, yang secara jelas dituntut berdasarkan kontrak dengan organisasi melainkan sebagai pilihan personal (MacKenzie et al., 2001).Begitu pentingnya kedudukan organizational citizenship behaviour sebagai salah satu bentuk kinerja extra-role, telah menarik perhatian dan perdebatan panjang dikalangan praktisi organisasi, peneliti maupun akademisi.Pembagian dan pengukuran organizational citizenship behavior diturunkan secara historis dari tiga sumber. Salah satu sumber tersebut adalah taxonomy, yaitu kegiatan-kegiatan kooperatif anggota-anggota rekan kerja, tindakan protektif sistem atau subsistem, ide-ide kreatif untuk perbaikan, self-training untuk meningkatkan tanggung jawab individual, dan pemeliharaan sikap organisasi kepada para stakeholder eksternal dan konstituennya (Luthans, 2011). yang lebih rendah, yang diminta untuk menggambarkan tindakan-tindakan yang mereka sukai dilakukan oleh para bawahan mereka namun tidak mereka minta, dan yang tidak dapat mereka janjikan imbalan-imbalan spesifik (selain dari rasa terima kasih).

\section{Perceived Organizational Support}

Di dalam suatu organisasi banyak masalah yang di kaitkan dengan dukungan organisasi, apabila dukungan organisasi yang berupa penyediaan sumber daya manusia, sarana dan prasarana kerja untuk memenuhi dan merangsang berbagai kebutuhan kerja anggota maka sumbangan dukungan organisasi terhadap kepuasan kerja dan motivasi kerja anggota organisasi sangatlah besar bagi setiap anggota untuk meniti karir dengan sebaik-baiknya. Dalam organisasi, interaksi sosial bisa terjadi dalam konteks individu dengan organisasinya.Terkait dengan itu, konsep dukungan organisasi mencoba menjelaskan interaksi individu dengan organisasi yang secara khusus mempelajari bagaimana organisasi memperlakukan individuindividu (anggotanya).Dukungan organisasi di pandang sangat penting bagi perilaku pekerjanya.Perceived organizational support didefinisikan oleh Krishnan dan Mary (2012) sebagai pendapat karyawan tentang sejauh mana mereka dihargai dan diakui oleh organisasi mereka.Selanjutnya, (Rhodes \& Eisenberger, 2002) juga mendefinisikan persepsi dukungan organisasi sebagai kompensasi, penghargaan, dan perawatan untuk kesejahteraan karyawan. Karyawan percaya bahwa majikan harus mengurus kebutuhan sosial, emosional dan mengompensasikan mereka ketika mereka meningkat upaya mereka di tempat kerja (Krishan \& Mary, 2012). Selain itu, beberapa faktor dikenal sebagai penggantian dukungan organisasi seperti imbalan dan kompensasi, kondisi kerja dan keadilan (Baran, Shanock \& Miller, 2012).

\section{Procedural Justice}

Prosedural justice atau keadilan procedural adalah keadilan yang dirasakan dari proses yang digunakan untuk menentukan distribusi imbalan (Robbins \& Judge, 2015). Pada penelitian ini keadilan prosedural yang diukur yaitu untuk mengetahu sejauhmana keadilan yang dirasakan pegawai dalam memperoleh distribusi imbalan.(Gibson, 2009) menyatakan bahwa keadilan prosedural berhubungan dengan kepuasan kerja, mengingat keadilan prosedural berhubungan dengan pelaksanaan prosedur bagi pegawai untuk mendapatkan kompensasi. Ketika pegawai merasakan keadilan dalam memperoleh kompensasi diyakini kepuasan kerja dalam diri pegawai akan terwujud. Keadilan procedural juga berhubungan dengan perlakuan yang diterima pegawai pada saat berusaha memperoleh kompensasi. Proses tersebut dilakukan dengan keseriusan dan 
pengorbanan waktu dan tenaga dalam bekerja. Semakin tinggi keadilan procedural yang dirasakan pegawai akan mendorong meningkatnya nilai kepuasan kerja yang dirasakan pegawai.Selain itu, evaluator secara jelas menjelaskan dasar evaluasi dan selanjutnya membahas bagaimana evaluasi tersebut diterjemahkan ke dalam hasil lain, seperti promosi dan peningkatan gaji/upah. Apabila pegawai mempersepsikan tingkat keadilan procedural tinggi, maka mereka cenderung termotivasi untuk berpartisipasi dalam aktivitas-aktivitas, mengikuti aturan-aturan, dan menerima hasil yang relevan sebagai sesuatu fair. Tetapi jika pegi mempersepsikan lebih banyak ketidakadilan procedural, maka mereka cenderung menarik diri dari kesempatan berpartisipasi, kurang memperhatikan aturan dan kebijakan, dan melihat hasil yang relevan sebagai sesuatu yang tidak fair. Lebih dari itu, persepsi ketidakadilan procedural mungkin disertai dengan penafsiran yang didasarkan kekuasaan dan perilaku politik orang/pihak lain (Kaswan, 2015).

\section{Kepuasan Kerja}

Kepuasan kerja sebagai suatu sikap umum seorang individu terhadap pekerjaannya, selisih antara banyaknya imbalan yang diterima seorang pekerja dan mereka yakini yang seharusnya mereka terima.Kepuasan kerja ditentukan oleh beberapa faktor yakni kerja yang secara mental menantang, kondisi kerja yang mendukung, rekan kerja yang mendukung, keadilan yang diterapkan, serta kepribadian dengan pekerjaan (Robbins \& Judge, 2015).Sementara itu (Handoko, 2000) menyatakan bahwa kepuasan kerja (job satisfaction) adalah keadaan emosional yang menyenangkan atau tidak menyenangkan mengenai bagaimana para karyawan memandang pekerjaan mereka.Kepuasan kerja mencerminkan perasaan seseorang terhadap pekerjaannya.Kepuasan kerja berhubungan dengan variabel-variabel seperti keadilan prosedural, turnover, tingkat absensi, umur, tingkat pekerjaan, dan ukuran organisasi perusahaan (Mangkunegara, 2007).

Kepuasan kerja berhubungan dengan keadilan prosedural mengandung arti bahwa keadilan prosedural yang baik yang diterapkan oleh perusahaan dihubungkan dengan kepuasan kerja yang tinggi pada karyawan dan dibuktikan dengan kinerja karyawan yang baik. Teori kepuasan kerja mencoba mengungkapkan apa yang membuat sebagian orang lebih puas terhadap suatu pekerjaan daripada beberapa lainnya. Dengan demikian, dapat disimpulkan bahwa kepuasan kerja karyawan merupakan perasaan emosional yang ditimbulkan oleh karyawan terhadap pekerjaan mereka sendiri.Kepuasan kerja didefenisikan sebagai suatu sikap bahwa individu memiliki dorongan sekitar pekerjaan mereka.Itu adalah sejauh mana orang merasa positif atau negatif tentang intrinsik / ekstrinsik aspek dari pekerjaan seseorang (Bhuian \& Menguc, 2002).Kepuasan kerja dapat mempengaruhi berbagi sikap yang penting, niat dan perilaku dalam angkatan kerja.Untuk akurat mengukur Kepuasan kerja, sebuah jumlah karakteristik pekerjaan mungkin perlu dievaliasi jika satu harapan untuk memperoleh ukuran luas keyakinan karyawan dan sikap tentang pekerjaan.

\section{Kerangka Konseptual}

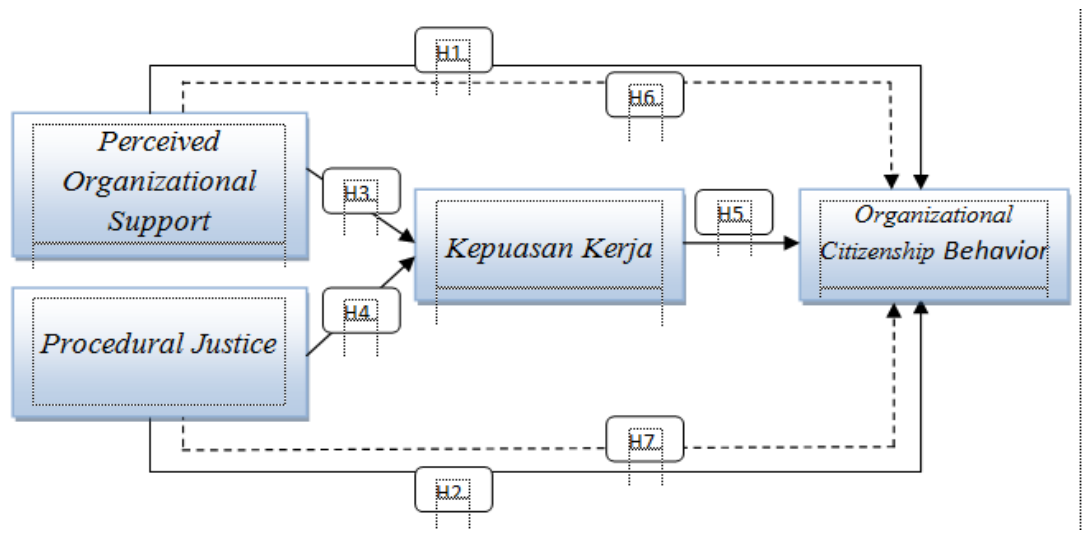


Gambar 1.2 Kerangka Pemikiran

Sumber : Dikembangkan sesuai dengan penelitian, 2020

$\mathrm{H}_{1} \quad$ : Perceived Organizational Support berpengaruh positif dan signifikan terhadap Organizational Citizenship Behavior pada perawat RSUD Rasyidin Padang.

$\mathrm{H}_{2}$ : Procedural Justice berpengaruh positif dan signifikan terhadap Organizational Citizenship Behavior pada perawat RSUD Rasyidin Padang.

$\mathrm{H}_{3} \quad$ : Perceived Organizational Support berpengaruh positif terhadap Kepuasan Kerja.

$\mathrm{H}_{4} \quad$ : Prosedural Justice berpengaruh positif dan signifikan terhadap Kepuasan Kerja.

$\mathrm{H}_{5} \quad$ : Kepuasan Kerja berpengaruh positif terhadap Organizational Citizenship Behavior.

$H_{6} \quad$ : Kepuasan Kerja menjadi mediasi pada hubungan Perceived Organizational Support dan Organizational Citizenship Behavior.

$\mathrm{H}_{7}$ : Kepuasan Kerja menjadi pemediasi pada hubungan Procedural Justice dan Organizational Citizenship Behavior.

\section{B. METODE PENELITIAN}

\section{Desain Penelitian}

Penelitian ini merupakan penelitian kuantitatif yaitu penelitian yang menuntut penggunaan angka, mulai dari pengumpulan data, penafsiran terhadap data tersebut, serta penampilan dari hasilnya. Adapun tujuan dalam penelitian tersebut adalah pengujian hipotesis, dimana biasanya menjelaskan sifat hubungan tertentu, atau lebih menentukan perbedaan antar kelompok atau kebebasan (independensi) dua atau lebih faktor dalam suatu situasi (Sekaran \& Bougie, 2016).

\section{Populasi dan Sampel}

Populasi merupakan kesatuan atribut yang saling bekerja sama untuk mencapai satu tujuan. Didalam penelitian yang menjadi populasi seluruh perawat di Rumah Sakit Daerah Rasyidin Padang yang berjumlah 137 orang.Mengingat jumlah populasi yang relatif besar mendorong peneliti untuk melakukan pengambilan sampel.Menurut Sekaran \& Bougie (2016) sampel merupakan bagian dari populasi yang dianggap mewakili.Didalam penelitian ini yang menjadi sampel adalah beberapa orang perawat Rumah Sakit Umum Daerah Rasyidin Padang.Untuk menentukan jumlah sampel menggunakan tabel penentuan sampel yang dikembangkan oleh Sekaran (2006)untuk jumlah populasi sebesar 137 orang, maka jumlah sampel yang digunakan sebanyak 100 responden.

\section{Tabel 2. Defenisi Operasional Variabel}

\begin{tabular}{|c|c|c|c|}
\hline No & Variabel & Devenisi Variabel & Dimensi \\
\hline 1 & $\begin{array}{l}\text { Perceived } \\
\text { Organizational } \\
\text { Support }\end{array}$ & $\begin{array}{l}\text { Pandangan yang dimiliki } \\
\text { pegawai terhadap dukungan } \\
\text { yang diberikan organisasi } \\
\text { dalam } \\
\text { terlaksananya } r \text { mendorong } \\
\text { jawab tanggung } \\
\text { pegawai masing-masing }\end{array}$ & 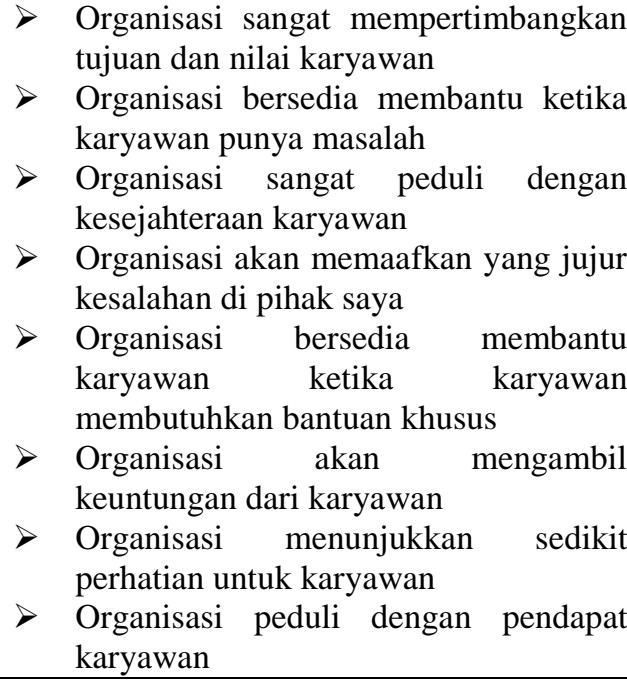 \\
\hline
\end{tabular}




\begin{tabular}{|c|c|c|c|}
\hline 2 & $\begin{array}{l}\text { Procedural } \\
\text { Justice }\end{array}$ & $\begin{array}{l}\text { Proses keadilan dalam } \\
\text { penilaian prestasi kerja yang } \\
\text { dilakukan oleh periodik, } \\
\text { penilaian prestasi kerja yang } \\
\text { dilakukan oleh supervisor } \\
\text { dan penilaian prestasi yang } \\
\text { dilakukan oleh diri pribadi. }\end{array}$ & 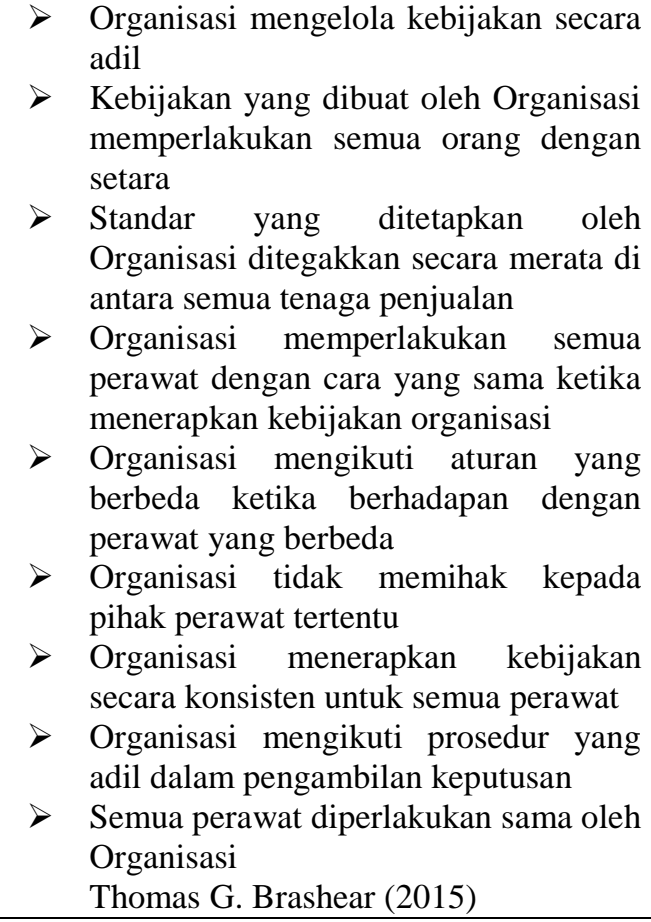 \\
\hline 3 & Kepuasan Kerja & $\begin{array}{l}\text { Kepuasan kerja karyawan } \\
\text { merupakan perasaan } \\
\text { emosional yang ditimbulkan } \\
\text { oleh karyawan terhadap } \\
\text { pekerjaan mereka sendiri. }\end{array}$ & $\begin{array}{l}>\quad \begin{array}{l}\text { Kepuasan dengan gaji (satisfaction } \\
\text { with pay) }\end{array} \\
>\quad \begin{array}{l}\text { Kepuasan dengan promosi (satisfaction } \\
\text { with promotion) }\end{array} \\
>\quad \begin{array}{l}\text { Kepuasan dengan rekan kerja } \\
\text { (satisfaction with coworkers) }\end{array} \\
>\quad \begin{array}{l}\text { Kepuasan dengan pekerjaan itu sendiri } \\
\text { (satisfaction wirh work itself) }\end{array} \\
\text { Diadaptasi dari Celluci, Athony J. dan David } \\
\text { L. De Vries (1978) dalam Mas'ud (2004) }\end{array}$ \\
\hline 4 & $\begin{array}{c}\text { Organizational } \\
\text { Citizenship } \\
\text { Bahavior } \\
\text { (OCB) }\end{array}$ & $\begin{array}{l}\text { Perilaku didalam organisasi } \\
\text { untuk memberikan waktu } \\
\text { yang lebih luas untuk } \\
\text { organisasi, serta memiliki } \\
\text { perilaku yang muncul } \\
\text { dengan kesadaran diri untuk } \\
\text { membantu setiap elemen } \\
\text { organisasi dalam bekerja }\end{array}$ & $\begin{array}{l}\text { 1. Alturism } \\
\text { Bersedia membantu orang lain yang } \\
\text { memiliki banyak pekerjaan yang berat } \\
\text { Bersedia membantu orang lain yang } \\
\text { tidak hadir } \\
\text { 2. Courtesy } \\
\text { Akan mempertimbangkan dampak } \\
\text { tindakan saya terhadap rekan kerja } \\
\text { Akan mengambil langkah untuk } \\
\text { mencoba mencegah masalah dengan } \\
\text { pekerja lain } \\
\text { 3. Conscientiousnes } \\
\text { Tidak mengambil istirahat tambahan } \\
\text { Mengikuti aturan dan peraturan } \\
\text { perusahaan bahkan ketika tidak ada } \\
\text { yang melihat } \\
\text { 4. Civic Virtue } \\
\text { Mengikuti perubahan dalam organisasi } \\
\text { Menghadiri pertemuan yang tidak } \\
\text { wajib, tetapi dianggap penting } \\
\text { 5. Sportsmanship } \\
\text { Mendapatkan perhatian karena karena } \\
\text { menunjukkan masalah } \\
\text { (Mohamed, 2016) }\end{array}$ \\
\hline
\end{tabular}

Sumber: Penelitian Terdahulu 


\section{HASIL DAN PEMBAHASAN}

Penelitian ini akan menggunakan metode analisis Partial Least Square 3.0 (PLS). Seperti dinyatakan oleh (Ghozali \& Latan, 2012), PLS merupakan metode analisis yang powerfull karena tidak didasarkan banyak asumsi. Data tidak harus berdistribusi normal multivariate (indikator dengan skala kategori, ordinal interval sampai rasio dapat digunakan pada model yang sama). Selain dapat digunakan untuk mengkonfirmasi teori, PLS juga dapat digunakan untuk menjelaskan ada atau tidaknya hubungan antar variabel laten. Oleh karena lebih menitikberatkan pada data dan dengan prosedur estimasi yang terbatas, maka mengspesifikasi model tidak begitu berpengaruh terhadap estimasi parameter. Analisis PLSSEM biasanya terdiri dari dua sub model yaitu model pengukuran (measurement model) atau sering disebut outer model dan model struktural (structural model) atau yang sering disebut inner model (Ghozali \& Latan, 2012).

\section{Uji Validitas Diskriminan}

Discriminant validity dinilai berdasarkan cross loading, jika korelasi konstruk dengan item pengukuran lebih besar dari pada ukuran konstruk lainnya, maka hal ini menunjukkan bahwa konstruk laten memprediksi ukuran pada blok mereka lebih baik dari pada ukuran pada blok lainnya. Untuk nilai cross loading apabila nilai korelasi konstruk dengan item pengukuran lebih besar daripada nilai korelasi dengan konstruk lainnya, maka hal tersebut menunjukan bahwa konstruk laten memprediksi ukuran pada blok mereka lebih baik daripada ukuran blok lainnya (Ghozali \& Latan, 2012). Sebelum dilakukannya pengujian validitas diskriminan, harus dilakukan dulu uji validitas konvergen, yang berguna untuk melihat setiap item indikator sudah valid atau tidak, dimana dilihat dari nilai setiap indikator harus lebih besar dari 0,7. Selanjutnya dilakukan uji validitas diskriminan yang berguna untuk melihat hubungan antar variabel dengan melihat seberapa jauh perbedaan nilai validitas suatu variabel jika dibandingkan dengan varibel lain.

Tabel 3.HasilValiditas Diskriminan

\begin{tabular}{|c|c|c|c|c|}
\hline & KK & OCB & POS & PJ \\
\hline KK & 0,859 & & & \\
\hline OCB & 0,725 & 0,770 & & \\
\hline POS & 0,779 & 0,750 & 0,861 & \\
\hline PJ & 0,610 & 0,643 & 0,635 & 0,820 \\
\hline
\end{tabular}

Sumber: dataprimer diolah 2020

Tabel 3 menunjukkan nilai akar kuadrat AVE pada variable organizational citizenship behavior sebesar 0,770. Nilai tersebut lebih besar dari nilai korelasi antara variabel organizational citizenship behavior dengan variable lainnya. Nilai akar kuadrat AVE pada variabel kepuasan kerja sebesar 0,859. Nilai tersebut lebih besar dari nilai korelasi antara variabel kepuasan kerjalainnya. Nilai akar kuadrat AVE pada variable perceived organizational support 0,861. Nilai tersebut lebih besar dari nilai korelasi antara variable perceived organizational support dengan variabel lainnya. Dengan demikian nilai akar kuadrat AVE lebih besar dari nilai korelasiantar variable lainnya. Artinya bahwa seluruh variable laten dalam penelitian ini mempunyai validitas diskriminan yang baik. Nilai akar kuadrat AVE pada variabel procedural justice sebesar0,820. Nilai tersebut lebih besar dari nilai korelasi antara variabel procedural justice dengan variabel lainnya.

Tabel 4.HasilPengujianAVE

\begin{tabular}{|l|c|}
\hline & Average Variance Extracted (AVE) \\
\hline Kepuasan Kerja & 0,737 \\
\hline Organizational Citizenship Behavior & 0,593 \\
\hline
\end{tabular}




\begin{tabular}{|l|c|}
\hline Perceived Organizational Support & 0,741 \\
\hline Prosedural Justice & 0,672 \\
\hline
\end{tabular}

Sumber: dataprimer diolah 2020

Tabel4 menunjukkan bahwa nilai AVE dari keseluruhan variable laten berkisarantara0, 593 sampai0, 741 artinya bahwa nilai AVE seluruh variabel lebih besar dari0,5. Hasil tersebut menunjukkan bahwa seluruh variable laten yang digunakan dalam penelitian ini mempunyai validitas diskriminan yang baik.

\section{Reliabilitas Komposit}

Reliabilitas kompsit merupakan reabilitas untuk mengukur variabel laten. Reliabilitas ini menggunakan koefisien reliabilitas untuk menjelaskan model pengukuran yang diuji.Koefisien ini merupakan koefisien konsistensi internal yang mendekati nilai koefisien internal Cronbach.Koefisien relibilitas ini cocok untuk pengkuran konjenerik yg mengansumsikan bahwa presisi dan skala ukur antar indiktor memiliki perbedan. Kelompok Indikator yang mengukur sebuah variabel memilki relabilitas komposit yang baik jika memiliki reliabilitas komposit $\geq 0,7$ meskipun bukan merupkan standar absolut.

Tabel 5.ReliabilitasKomposit

\begin{tabular}{|l|c|c|}
\hline & Cronbach's Alpha & Composite Reliability \\
\hline Kepuasan Kerja & 0,911 & 0,933 \\
\hline Organizational Citizenship Behavior & 0,914 & 0,929 \\
\hline Perceived Organizational Support & 0,949 & 0,958 \\
\hline Prosedural Justice & 0,930 & 0,942 \\
\hline
\end{tabular}

Sumber: dataprimer diolah 2020

Tabel5menunjukkanbahwa nilai Cronbach's Alpha danComposite Reliabilityseluruhvariabel penelitian lebih besar dari 0.7, artinyabahwa seluruh variabel penelitian dinyatakan handal, maka variabel penelitian dapat digunakan pada tahapan selanjutnta.

\section{Uji Kesesuaian Model (Goodness of fit)}

Pemeriksaan terhadap model struktual dilakukan dengan melihat nilai Rsquare.Penilaian model dengan PLS dimulai dengan melihat R-square untuk setiap variabel laten dependen. Perubahan nilai R-square dapat digunakan untuk menilai pengaruh variabel laten independen tertentu terhadap variabel laten dependent apakah menpunyai pengaruh yang substantif.

Tabel 6

HasilPengujian R-Square

\begin{tabular}{|l|c|c|}
\hline & R Square & R Square Adjusted \\
\hline Kepuasan Kerja & 0.629 & 0.621 \\
\hline Organizational Citizenship Behavior & 0.641 & 0.629 \\
\hline
\end{tabular}

Sumber: dataprimer diolah 2020

Nilai $R$-square merupakan hasil (berupa persentase) atas representasi variable independen terhadap variable dependen. Nilai $\mathrm{R}^{2}$ yang tertera pada Tabel 5 dapat dijelaskan bahwa:

1. NilaiR Square Adjusted variable organizational citizenship behavior sebesar 0,629. Maka dapat disimpulkan bahwa pengaruh variable perceived organizational support, procedural justice dan Kepuasan Kerja terhadap organizational citizenship behavior sebesar62.9\%. Sementara $37.1 \%$ dipengaruhi oleh variabel lainnya yang tidak dijelaskan dalam penelitian ini. 
2. Nilai RSquare Adjusted variabel Kepuasan Kerja sebesar 0,621. Maka dapat disimpulkanbahwa pengaruh variable perceived organizational support, procedural justice terhadap Kepuasan Kerja sebesar 62.1\%. Sementara 37.9\% dipengaruhi oleh variabel lainnya yang tidak dijelaskan dalam penelitian ini.

\section{Uji Path Coefficients}

Uji hipotesis ini merupakan analisis kausalitas yg dilakukan untuk mengetahui hubungan antar variabel. Analisis kausalitas dapat digunakan untuk mengetahui pengaruh yg terjadi antara variable eksogen dengan variabel endogen. Variabel eksogen dinyatakan berpengaruh secara signifikan terhadap variabel endogen jika nilai tstatistik $>$ ttabel.

Tabel 7.Pacth Coefficient

\begin{tabular}{|l|c|c|c|}
\hline & Original Sample $(\mathrm{O})$ & T Statistics $(|\mathrm{O} / \mathrm{STDEV}|)$ & P Values \\
\hline KK $->$ OCB & 0,292 & 2,401 & 0,017 \\
\hline POS -> KK & 0,657 & 8,295 & 0,000 \\
\hline POS -> OCB & 0,382 & 2,304 & 0,022 \\
\hline PJ -> KK & 0,193 & 2,391 & 0,017 \\
\hline PJ -> OCB & 0,222 & 2,179 & 0,030 \\
\hline
\end{tabular}

Sumber: dataprimer diolah 2020

Berdasarkan tabel $7 \mathrm{di}$ atas dapat dikatakan bahwa setiap variabel langsung memiliki nilai hipotesis signifikan dan positif karena nilai orignial sampel lebih dari 0 , dan $\mathrm{T}$ statistik besar dari $\mathrm{T}$ tabel yaitu 1,96. Atau juga bisa melihat dari $\mathrm{P}$ values harus lebih kecil dari 0.05 .

\section{MenghitungVAF}

Pengaruh variabel independen terhadap variabel dependen tidak secara langsung terjadi, tetapi melalui proses transformasi yang diwakili oleh variabel mediasi. Prosedur pengujian mediasi dalam PLS dengan metode VAF.Jika nilai VAF diatas $80 \%$ maka menunjukkan peran M sebagai pemediasi penuh (full mediation). M dikategorikan sebagai pemediasi parsial apabila nilai VAF berkisar antara 20\% sampai dengan $80 \%$, namun jika VAF kurang dari $20 \%$ dapat disimpulkan bahwa hampir tidak ada efek mediasi.

Tabel 8.Total Effect

\begin{tabular}{|l|c|c|c|}
\hline & Original Sample & Sample Mean & Standard Deviation \\
\hline POS -> OCB & 0,382 & 0,381 & 0,166 \\
\hline POS -> KK -> OCB & 0,192 & 0,198 & 0,090 \\
\hline PJ -> OCB & 0,222 & 0,222 & 0,102 \\
\hline PJ -> KK-> OCB & 0,056 & 0,053 & 0,032 \\
\hline
\end{tabular}

Sumber: dataprimer diolah 2020

Perhitungan nilai VAF untuk setiap hubungan dapat dijelaskan sebagai berikut:

1. Perhitungan nilai VAF untuk melihat peranan Kepuasan Kerja sebagai variabel mediasi antara perceived organizatonal support dan organizational citizenship behavior sebagai berikut:

$$
\mathrm{VAF}=\quad \text { Pengaruh Tidak Langsung }
$$

\section{Pengaruh Langsung + Pengaruh Tidak Langsung}

Bisa dilihat pada tabel 4.16 nilai koefisiennya dari pengaruh tidak langsung adalah 0,192 (nilai koefisien dari kepuasan kerja sebagai variabel mediasi antara perceived organizatonal support danorganizational citizenship behavior). Sedangkan pengaruh langsung dilihat dari pengaruh perceived organizatonal support terhadap organizational citizenship behavior yang mempunyai nilai koefisien sebesar 0,382. Menghitung VAF sesuai dengan formula :

$$
\mathrm{VAF}=\quad 0,192
$$




$$
\begin{aligned}
& \mathrm{VAF}=\frac{(0,382+0,192)}{0,192} \\
& \mathrm{VAF}=0,374
\end{aligned}
$$

2. Perhitungan nilai VAF untuk melihat peranan kepuasan kerja sebagai variabel mediasi antara prosedural justice dan organizational citizenship behavior sebagai berikut:

$$
\mathrm{VAF}=
$$
Pengaruh Tidak Langsung

Pengaruh Langsung + Pengaruh Tidak Langsung

Bisa dilihat pada tabel 4.16 nilai koefisiennya dari pengaruh tidak langsung adalah 0,056 (nilai koefisien dari Kepuasan Kerja sebagai variabel mediasi antara prosedural justice dan organizational citizenship behavior).Sedangkan pengaruh langsung dilihat dari pengaruh prosedural justiceterhadap organizational citizenship behavior yang mempunyai nilai koefisien sebesar 0,222. Menghitung sesuai VAF dengan formula :

$$
\begin{aligned}
\mathrm{VAF} & =\frac{0,056}{(0,222+0,056)} \\
\mathrm{VAF} & =\frac{0,056}{0,278} \\
\mathrm{VAF} & =0,201 \text { atau 20,14\% (Mediasi Sebagian) }
\end{aligned}
$$

\section{PEMBAHASAN}

\section{Pengaruh Perceived Organizational Support terhadap Organizational Citizenship Behavior}

Berdasarkan hasil penelitian ditemukan bahwa perceived organizational support berpengaruh positif dan signifikan terhadap organizational citizenship behavior, artinya perceived organizational support (dukungan organisasi) dapat menciptakan atau membentuk prilaku organizational citizenship behavior pada perawat di RSUD Rasydin Padang. Ketika dukungan yang diberikan organisasi sesuai dengan pengorbanan yang diberikan maka pegawai akan lebih mencurahkan perhatiannya kepada organisasi, seperti memberikan banyak waktu untuk kepentingan organisasi, serta menciptakan suasana kerja nyaman dan menjalin kerja sama yang kuat dengan sesama pegawai.

\section{Pengaruh Procedural JusticeterhadapOrganizational Citizenship Behavior}

Berdasarkan hasil penelitian ditemukan bahwa procedural justiceberpengaruh positif dan signifikan terhadap organizational citizenship behavior, artinya procedural justicedapat menciptakan atau membentuk prilaku organizational citizenship behavior pada perawat di RSUD Rasydin Padang.Semakin adil prosedur yang dirasakan pegawai untuk mendapatkan sebuah posisi mendorong muncul persaingan yang sehat didalam organisasi.Kesesuaian prosedur menciptakan lingkungan kerja yang dinamis dan harmonis yang diperlihatkan dari adanya sikap saling menghormati antara pegawai tinggi tingkat kesulitan team yang melibatkan seluruh pegawai dalam bekerja.

\section{Pengaruh Perceived Organizational Support terhadap Kepuasan Kerja}

Berdasarkan hasil penelitian ditemukan bahwa perceived organizational support berpengaruh positif dan signifikan terhadap kepuasan kerja, artinya perceived organizational support dapat menciptakan atau membentuk prilaku kepuasan kerja pada perawat di RSUD Rasydin Padang.

\section{PengaruhProcedural Justice terhadap Kepuasan Kerja}

Berdasarkan hasil penelitian ditemukan bahwa procedural justice berpengaruh positif dan signifikan terhadap kepuasan kerja, artinya procedural justice dapat menciptakan atau membentuk prilaku Kepuasan Kerja pada perawat di RSUD Rasydin Padang.Hal ini berarti 
semakin pegawai merasakan adanya keadilan dalam prosedur yang digunakan perusahaan maka akan semakin puas perasaan karyawan atas pekerjaan mereka, begitu juga sebaliknya jika karyawan merasakan kurangnya keadilan pada prosedur yang digunakan dalam perusahaan maka akan berkurang perasaan puas karyawan pada pekerjaan mereka.

\section{Pengaruh Kepuasan Kerja terhadapOrganizational Citizenship Behavior}

Berdasarkan hasil penelitian ditemukan bahwa kepuasan kerjaberpengaruh positif dan signifikan terhadap organizational citizenship behavior, artinya kepuasan kerjadapat menciptakan atau membentuk prilaku organizational citizenship behavior pada perawat di RSUD Rasydin Padang.kepuasan kerja berpengaruh signifikan terhadap organizational citizenship behavior (OCB), karena kepuasan kerja dan komitmen organisasi menimbulkan motivasi pada diri karyawan dan rasa memiliki terhadap organisasi sehingga dengan sendirinya karyawan akan memberikan umpan balik berupa perilaku organizational citizenship behavior (OCB).

\section{Kepuasan Kerja berperan sebagai pemediasi antara Procedural JusticePerceived Organizational dan Organizational Citizenship Behavior}

Berdasarkan hasil penelitian ditemukan bahwa kepuasan kerjaberperan sebagai mediasi parsial antara perceived organizational supportdan procedural justice terhadap organizational citizenship behavior, artinya perceived organizational supportdan procedural justicedapat menciptakan atau membentuk kepuasan kerjadan pada akhirnya dapat membentuk prilaku organizational citizenship behavior pada perawat di RSUD Rasydin Padang.Kepuasan karyawan dapat didefinisikan sebagai perasaan senang maupun tidak senang yang dirasakan oleh karyawan.Perasaan tersebut muncul berawal dari perlakuan perusahaan terhadap karyawan.Perasaan tersebut ditunjukkan dengan adanya sikap keadilan dan dukungan dari organisasiyang diberikan oleh perusahaan.Keadilan prosedural didapatkan karyawan dari persepsi mereka atas proses yang diterapkan oleh atasan untuk mengevaluasi kinerja karyawan, sedangkan keadilan organisasi yang diberikanakan memunculkan rasa puas dalam bekerja dan akan mendorong prilaku organizational citizenship behaviorpada perawat di RSUD Rasydin Padang.

\section{PENUTUP}

Berdasarkan hasil pengujian hipotesis dan pembahasan maka dapat diambil kesimpulan bahwa Perceveid organizational support berpengaruh positif dan signifikan terhadap organizational citizenship behavior pada RSUD Rasyidin Padang, Prosedural justice berpengaruh positif dan signifikan terhadap organizational citizenship behavior pada RSUD Rasyidin Padang, Perceveid organizational support berpengaruh positif dan signifikan terhadap kepuasan kerja pada RSUD Rasyidin Padang, Prosedural justice berpengaruh positif dan signifikan terhadap kepuasan kerja pada RSUD Rasyidin Padang, Kepuasan kerja berpengaruh positif dan signifikan terhadap organizational citizenship behavior pada RSUD Rasyidin Padang, Kepuasan kerja berperan sebagai mediasi parsial antara perceveid organizational support dan organizational citizenship behavior pada RSUD Rasyidin Padang. Kepuasan kerja berperan sebagai mediasi parsial antara Prosedural justice dan organizational citizenship behavior pada RSUD Rasyidin Padang.

\section{E. DAFTAR PUSTAKA}

Baran, B. E., Shanock, L. R., \& Miller, L. R. 2012.Advancing organizational support theory into the twenty-first century world of work.Journal of Business andPsychology, 27(2), 123147. 
Bhuian, S. N., \& Menguc, B. (2002). Evaluation of Job Characteristics, Organizational Commitment and Job Satisfaction in an Expatriate, Guest Worker, Sales Setting. Journal of Personal Selling and Sales Management.

Gibson, et al. (2009). Organizational: Behavior, Structure, Processes. New York: The McGraw Hill Companies, Inc.

Ghozali, I., \& Latan, H. (2012). Partial Least Square. Konsep, Teknik dan Aplikasi SmartPLS 2.0. Badan Penerbit Universitas Diponegoro.

Handoko T. Hani. 2000.Manajemen Personalia dan Sumberdaya Manusia, Edisi II, Cetakan Keempat Belas, Penerbit BPFE, Yogyakarta.

Luthans, Fred. 2011. Perilaku organisasi. Yogayakarta : Andi.

Kaswan, Akhyadi. 2015. Pengembangan Sumber Daya Manusia . Bandung, Indonesia : Alfabeta.

Krishnan, J., \& Mary, V. S. 2012.Perceived organizational support-an overview on itsantecedents and consequences.International Journal of Multidisciplinary Research, 2(4),1016-1022.

MacKenzie, S. B., Podsakoff, P. M., \& Rich, G. A. 2001.Transformational and transactional leadership and salesperson performance.Journal of the Academy of Marketing Science, 29(2), 115-134.

Mangkunegara, Anwar Prabu. 2007.Manajemen Sumber Daya Manusia, Cetakan Ke Tujuh, Bandung: PT. Remaja Rosdakarya.

Fuad Mas'ud. 2004. "Survai Diagnosis Organisasional," Badan Penerbit Universitas Diponegoro, Semarang.

Mohamed. (2016). Investigating the Relationship between Job Satisfaction and Organizational Citizenship Behavior among Beni Suef Cement Company Employees. Arabian J Bus Manag Review. 